\title{
Ultrastructure of the early stages of Colletotrichum acutatum infection of strawberry tissues
}

\author{
Francisco T. Arroyo, Javier Moreno, Gregorio García-Herdugo, \\ Berta De los Santos, Carmen Barrau, María Porras, César Blanco, \\ and Fernando Romero
}

\begin{abstract}
The early stages of the infection of attached leaves and petioles of strawberry (Fragaria $\times$ ananassa Duch. 'Camarosa') by Colletotrichum acutatum Simmonds were studied using scanning and transmission electron microscopy. Pre-penetration events of these tissues were similar, but the production of secondary conidia (microcyclic conidiation) was detected only on leaves. At the ultrastructural level, different stages of maturation of appressoria were observed and described. In young appressoria, the cell wall was composed of two layers and the plasma membrane displayed a wavy appearance. In the following stage, the appressorium developed a third electron-transparent layer between the cell wall and the plasma membrane. This new electron-transparent material was especially visible in the region of the appressorium near the cuticle. The plasma membrane of this appressorium showed a smooth appearance. Afterwards, a penetration peg emerged through the pore penetrating the cuticle and reached the epidermal wall where it enlarged to form an intramural infection vesicle. Both structures of infection, the penetration peg and the intramural infection vesicle, produced during the early phases of infection of strawbery tissues by $C$. acutatum, have not been previously reported and confirm that its invasion strategy is that of a subcuticular intramural pathogen. Once the infection was well established, abundant subcuticular and intramural hyphae were produced on petioles, causing severe degradation of the host cell walls. Occasionally, the cuticle appeared disrupted in those regions where the host walls were very degraded and dilated. Differences between colonization of petioles and leaves were observed.
\end{abstract}

Key words: Colletotrichum acutatum, Fragaria xananassa, infection vesicle, invasion strategy, penetration peg.

Résumé : À l'aide de la microscopie électronique par balayage et par transmission, les auteurs ont étudié les premiers stades de l'infection des feuilles attachées et des pétioles du fraisier (Fragaria xananassa Duch. 'Camarosa'), par le Colletotrichum acutatum Simmonds. Les évènements de pré-pénétration de ces tissus sont similaires, mais la production de conidies secondaires (conidiation microcyclique) ne s'observe que sur les feuilles. Les auteurs ont observé et décrivent les ultrastructures, aux différents stades de maturation des appressoriums. Chez les jeunes appressoriums, la paroi cellulaire est composée de deux couches et la membrane plasmique montre une apparence ondulée. Au stade suivant, l'appressorium développe une troisième couche transparente aux électrons, entre la paroi cellulaire et la plasmalemme. Ce nouveau matériel transparent aux électrons est particulièrement visible dans la région de l'appressorium voisin de la cuticule. La plasmalemme de cet appressorium est d'apparence lisse. Par après, l'hyphe de pénétration émerge à travers le pore et pénètre la cuticule pour atteindre la paroi épidermique, où il s'élargit pour former une vésicule d'infection intramurale. Les deux structures d'infection, hyphe de pénétration et vésicule d'infection intramurale, produites au cours des premières phases d'infection des tissus du fraisier par le C. acutatum, n'ont jamais été rapportées jusqu'ici et confirment sa stratégie d'invasion par pathogénèse subcuticulaire intra murale. Une fois l'infection bien établie, on observe la formation de nombreux hyphes subcuticulaires et intramuraux sur les pétioles, entraînant la dégradation des parois des cellules de l'hôte. Occasionnellement, la cuticule apparaît éclatée dans les régions où les parois de l'hôte sont vraiment dégradées et dilatées. On observe des différences entre la colonisation des pétioles et des feuilles.

Mots clés : Colletotrichum acutatum, Fragaria ×ananassa, vésicule d'infection, stratégie d'invasion, hyphe de pénétration.

[Traduit par la Rédaction]

Received 21 July 2004. Published on the NRC Research Press Web site at http://canjbot.nrc.ca on 21 May 2005.

F.T. Arroyo, ${ }^{1}$ B. De los Santos, C. Barrau, M. Porras, C. Blanco, and F. Romero. Centro de investigación y formación agraria Las Torres-Tomejil, Apdo. de Correos Oficial, 41200 Alcalá del Río (Sevilla), Spain.

J. Moreno and G. García-Herdugo. Departamento de Biología Celular, Universidad de Sevilla, Sevilla, Spain.

${ }^{1}$ Corresponding author (e-mail: franciscot.arroyo@juntadeandalucia.es). 


\section{Introduction}

Strawberry (Fragaria xananassa Duch.) anthracnose is caused by species of the genera Colletotrichum and Gloeosporium. In the United States this disease is mainly caused by $C$. fragariae Brooks, C. gloeosporioides (Penz.) Penz. \& Sacc., and C. acutatum Simmonds (Howard et al. 1992). In Europe, only C. gloeosporioides and C. acutatum have been identified as pathogens causing anthracnose in strawberry (De los Santos and Romero 1999; Denoyes and Baudry 1995).

Spain is the major producer of strawberry fruit in the European Union. In this country more than $90 \%$ of the national production is located in the province of Huelva (southwestern Spain) (Hancock 1999). Anthracnose, caused by C. acutatum, is one of the most important diseases affecting strawberry production in this region, causing significant reductions in yield (De los Santos 1998).

Host colonization and pathogenesis are well characterised for several species of Colletotrichum (Dickman 2000; O'Connell et al. 1985). The initial stages of host infection by Colletotrichum spp. include conidial adhesion to the host surface, germination of conidia, production of germ tubes that differentiate to form melanized appressoria, and penetration of the host cuticle via appressoria (Dickman 2000).

According to Bailey et al. (1992), Colletotrichum spp. use primarily two infection strategies: intracellular hemibiotrophic invasion and subcuticular intramural invasion. In the first strategy, the pathogens exhibit a two-phase infection process: an initial symptomless or biotrophic phase, with hyphae growing within the cell lumen by means of a globose infection vesicle without perturbing the host plasma membrane, followed by a necrotrophic phase. Colletotrichum lindemuthianum infecting bean (Phaseolus vulgaris) or cowpea (Vigna unguiculata) (Bailey et al. 1990; Mercer et al. 1975; O'Connell et al. 1985; Skipp and Deverall 1972), C. trifolii infecting alfalfa (Medicago sativa) (Mould et al. 1991a, 1991b), and C. gloeosporioides infecting Malva spp. (Morin et al. 1996) are examples of species exhibiting this strategy. The subcuticular intramural invasion strategy is characterised by the growth of the pathogen beneath the cuticle and within the periclinal walls of epidermal cells (Bailey et al. 1990). Colletotrichum capsici (Pring et al. 1995), C. truncatum (Manandhar et al. 1985), C. circinans, and $C$. phomoides (Bailey et al. 1992) have been reported to use this strategy.

Colletotrichum acutatum is a pathogen affecting important crops world-wide; however, few studies have investigated the ultrastructure in strawberry systems (Curry et al. 2002). Leandro et al. (2001) reported the germination and the formation of secondary conidia of this pathogen on the surface of detached strawberry leaves. Horowitz et al. (2002) studied the development of $C$. acutatum on strawberry and other plant species by using transgenic isolates. Curry et al. (2002) studied the histopathology of $C$. acutatum and $C$. fragariae in strawberry stolons and petioles and described the process of infection, showing, at the ultrastructural level, stages of invasion of these pathogens with hyphae under host cuticle and in anticlinal host wall. However, infection structures during the penetration phase, such as a penetration peg or infection vesicle, of $C$. acutatum have not been described at the ultrastructural level. There are still some aspects of the infection process of $C$. acutatum on strawberry that remain poorly understood, especially those related to the earliest stages of penetration.

The purpose of this study was to characterise the infection structures of $C$. acutatum involved during the penetration phase and the early stages of infection in two strawberry tissues, petioles and leaves, that express different susceptibility to this pathogen and to clarify the invasion strategy used by C. acutatum with respect to strategies previously described by other authors.

\section{Materials and methods}

\section{Plant material}

Strawberry plants (Fragaria ×ananassa 'Camarosa') that are highly susceptible to C. acutatum (De los Santos 1998) were obtained by micropropagation techniques. Plants were planted in $10.5 \mathrm{~cm} \times 13.5 \mathrm{~cm}$ plastic pots containing sterilized peat (Klansmann-Deilmann, Geeste, Germany) and grown for $75 \mathrm{~d}$ before inoculation with $C$. acutatum in a greenhouse maintained at $25 \pm 5^{\circ} \mathrm{C}$ day : $15 \pm 5^{\circ} \mathrm{C}$ night.

\section{Inoculation}

Colletotrichum acutatum isolate CECT-20240 obtained from a naturally infected strawberry ('Chandler') crown was used in this study. The fungus was grown on potato dextrose agar (Difco Laboratories, Detroit, Michigan) for $7 \mathrm{~d}$ at $25^{\circ} \mathrm{C}$ under continuous fluorescent light (Osram L 18 W/21-840 Hellweiss Lumilux Cool White, $75 \mu \mathrm{E} \cdot \mathrm{m}^{-2} \cdot \mathrm{s}^{-1}$ ) (De los Santos 1998, De los Santos and Romero 1999).

Conidial suspensions were prepared by flooding the culture plates with $4-5 \mathrm{~mL}$ of sterile distilled water, scraping the colony surface with a scalpel, and filtering the suspension through sterile cheesecloth. The concentration was adjusted to $1 \times 10^{6}$ conidia $\cdot \mathrm{mL}^{-1}$ using a haemocytometer.

Attached petioles and both abaxial and adaxial surfaces of strawberry leaves were inoculated by applying $50-\mu \mathrm{L}$ droplets of conidial suspension (Arroyo et al. 2001). Inoculated plants were enclosed in plastic bags for $48 \mathrm{~h}$ to maintain high relative humidity and were incubated in a growth chamber at $25{ }^{\circ} \mathrm{C}$, with a 16 -h photoperiod beneath fluorescent light (Sylvania Luxline Plus F58W/840 Cool White Deluxe, $\left.100.5 \mu \mathrm{E} \cdot \mathrm{m}^{-2} \cdot \mathrm{s}^{-1}\right)$. Control plants were treated with $50 \mu \mathrm{L}$ of sterile distilled water and incubated as described above.

\section{Scanning electron microscopy}

To study conidial development of C. acutatum on strawberry tissues, or pre-penetration events, three petioles and six leaves were sampled at $4,8,12,24,48$, and $72 \mathrm{~h}$ after inoculation. Petiole segments $1 \mathrm{~cm}$ long and leaf disks $1 \mathrm{~cm}^{2}$ from beneath inoculation droplets were removed and fixed overnight at $4{ }^{\circ} \mathrm{C}$ in $4 \%(v / v)$ glutaraldehyde in $0.1 \mathrm{~mol} \cdot \mathrm{L}^{-1}$ phosphate buffer ( $\mathrm{pH} 7.2$ ), rinsed in buffer, and dehydrated through graded acetone to $100 \%$. Segments and disks were dried in a critical point drying apparatus (model No. CDP030, BAL-TEC Company, Balzers, Leichtenstein) and coated with gold. Observations and image collection were made using a Philips XL-20 scanning electron microscope (SEM) operating at $10 \mathrm{kV}$. 
Figs. 1-5. Conidial development of Colletotrichum acutatum on petioles and leaves of strawberry (SEM). Fig. 1. Sessile appressorium (A) and conidium (CO) with two transverse septa (arrows) on the adaxial leaf surface at $8 \mathrm{~h}$ post-inoculation (hpi). Scale bar $=5 \mu \mathrm{m}$. Fig. 2. Appressoria (A) on petiole at $24 \mathrm{hpi}$, with basal septa (arrows) originating from long germ tubes. Scale bar $=5 \mu \mathrm{m}$. Fig. 3 . Secondary conidium on the adaxial leaf surface at $48 \mathrm{hpi}$, originating from hyphal phialide (arrow). Scale bar $=5 \mu \mathrm{m}$. Fig. 4 . Secondary conidia on the adaxial leaf surface at $72 \mathrm{hpi}$, originating from hyphal phialide (arrowhead) and conidial phialide (arrows). Scale bar $=10 \mu \mathrm{m}$. Fig. 5. Secondary conidium (arrow) and appressorium (A) originated from a short germ tube on abaxial leaf surface at 72 hpi. Scale bar $=10 \mu \mathrm{m}$.
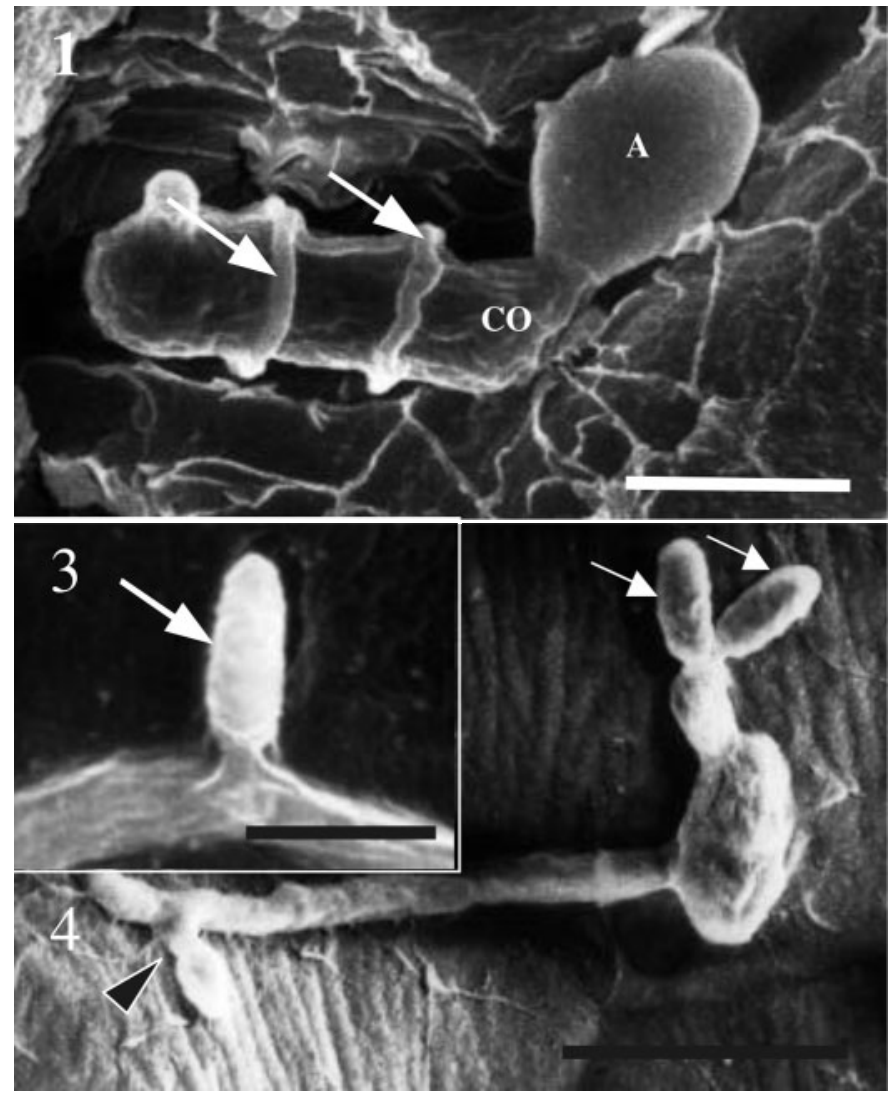

\section{Transmission electron microscopy}

To study the early stages of $C$. acutatum infection on strawberry tissues, three petioles and six leaves were sampled at 24, 36, and $48 \mathrm{~h}$ after inoculation. Strips of tissue approximately $1 \mathrm{~mm}$ thick and 1-2 $\mathrm{mm}$ long were removed from beneath the inoculation droplets on petioles and leaves and were fixed in $4 \%(\mathrm{v} / \mathrm{v})$ glutaraldehyde in $0.1 \mathrm{~mol} \cdot \mathrm{L}^{-1}$ cacodylate buffer ( $\mathrm{pH} 7.2)$ for $3 \mathrm{~h}$ at $4{ }^{\circ} \mathrm{C}$. After rinsing in the same buffer, the tissues were post-fixed in $1 \%(w / v)$ osmium tetroxide for $2 \mathrm{~h}$ at $4{ }^{\circ} \mathrm{C}$, then dehydrated in a graded acetone series, and embedded in EMBED-812 (Polysciences, Warrington, Penn.) according to the manufacturer's instructions.

Slides with semithin sections $(0.5 \mu \mathrm{m})$ were placed on a hotplate at $50{ }^{\circ} \mathrm{C}$, stained for $1 \mathrm{~min}$ with $0.1 \%$ aqueous toluidine blue $\mathrm{O}$, and examined using a light microscope (Leitz Aristoplan). Ultrathin 60-80 nm sections were made with a Reichert-Jung Ultracut E ultramicrotome and a diamond knife, and collected on 300-mesh copper grids (Dashek and Mayfield 2000). Grids were stained with 7\% aqueous uranyl acetate and lead citrate. Sections were observed and images collected using a Philips CM-10 transmission electron microscope (TEM).

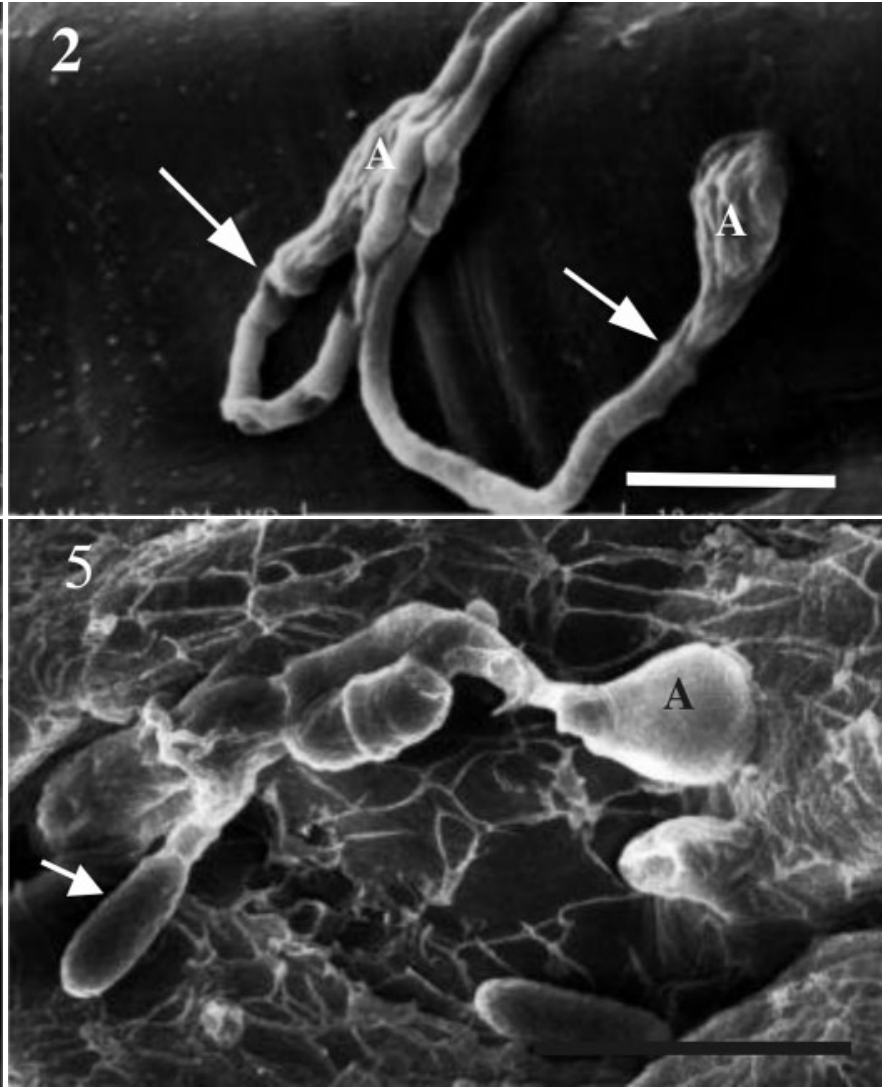

\section{Results}

\section{Scanning electron microscopy}

Most conidia began to germinate on petiole and foliar surfaces within $4 \mathrm{~h}$ after inoculation by forming a germ tube from either end of the conidium, and occasionally from both ends. Lateral germination was rarely observed. Germinated conidia typically developed one or two transverse septa. By $8 \mathrm{~h}$ after inoculation, globose and subglobose appressoria were detected as swellings of the germ tube tips. On leaves, especially on the adaxial surface, appressoria originated from short germ tubes (sessile appressoria) (Fig. 1). However, appressoria observed on petioles, at $24 \mathrm{~h}$ after inoculation, usually developed from elongated germ tubes, which often reached a length several times the conidium size. SEM revealed a septum between the germ tube and appressorium, near the base of the appressorium (Fig. 2). Appressoria were detected primarily near to the junction of the epidermal cells and, rarely, on stomata.

Microcyclic conidiation also was observed on either adaxial or abaxial surfaces of inoculated leaves, producing abundant secondary conidia from conidial and hyphal phialides (Figs. 3-5). However, these conidiogenic structures 
Figs. 6-10. Appressoria of Colletotrichum acutatum in different maturation stages on strawberry petioles at 24 hpi (TEM). Fig. 6. Young appressorium on cuticle (C) with a wavy plasma membrane (arrowhead), appressorial wall with an electron-transparent inner layer (open arrow) and electron-dense outer layer (solid arrow), surrounded by a mucilaginous coating (MU). Scale bar = $1 \mu \mathrm{m}$. Fig. 7 . Pore formation in the basal portion of appressorium (open arrow) where a new electron-transparent material (solid arrow) is formed between appressorial wall and plasma membrane (arrowhead). The fragmented nuclear envelope (white arrows) and nucleus (N) are also shown. Scale bar $=0.5 \mu \mathrm{m}$. Fig. 8. Appresorium with formed pore, dissolved wall (open arrow) in pore region, smooth plasma membrane (arrowhead), and electron-transparent material in pore (solid arrow). The fragmented nuclear envelope (white arrows) and the nucleus $(\mathrm{N})$ are also shown. Scale bar $=1 \mu \mathrm{m}$. Fig. 9. Enlargement of Fig. 8. The appressorium plasma membrane appears smooth except for the pore region where it is wavy (arrowhead). Scale bar $=0.5 \mu \mathrm{m}$. Fig. 10. Appressorium with infection pore and initiation of the penetration peg $(\mathrm{PP})$ formation. Scale bar $=0.5 \mu \mathrm{m}$. AW, appressorial wall; C, cuticle; HE, heterophagosome; HW, host cell wall; M, mitochondria.

were not detected on petioles. At $72 \mathrm{~h}$ after inoculation, anastomosed fungal masses were detected on inoculated tissues, especially on leaves, forming ball-shaped accumulations nearly $100 \mu \mathrm{m}$ in size (data not shown).

\section{Transmission electron microscopy}

Appressoria of $C$. acutatum were primarily located near the junction of the epidermal cells. At $24 \mathrm{~h}$ after inoculation, appressoria with different maturation stages and the earliest stages of penetration were observed on petioles (Figs. 6-10). Young (immature) appressoria, which had not yet developed the appressorial pore in the basal region, were observed. The cell wall of these appressoria was composed of two morphologically distinct layers: an outer electron-dense layer and an inner electron-transparent layer. In addition, a mucilaginous matrix, which had a fibrillar aspect, covered the cell wall. In these appressoria the plasma membrane had a wavy appearance and mitochondria were located in the cellular periphery (Fig. 6). In a more advanced appressorium stage, the width of the cell wall appeared quite reduced in the regions close to the cuticle, and both inner and outer layers were indistinguishable, displaying a moderately dense aspect (Fig. 7). In further stages of appressoria maturation, the cell wall close to the cuticle was completely dissolved to form a pore. In this region, the formation of a new electron-transparent layer between the cell wall and plasma membrane was observed connecting directly with the cuticle (Figs. 7, 8). The plasma membrane of these appressoria had a smooth aspect except in the pore region, where it displayed a wavy appearance (Fig. 9). A heterophagosome, with a myelin appearance, was observed around the pore region. The nuclei of these appressoria showed decondensed chromatin and its envelope was fragmented (Figs. 7-9).

Subsequently, the appressorium initiated the formation of a V-shaped penetration peg, which pushed the host cuticle (Fig. 10). The cell wall of the penetration peg was indistinct from the electron-transparent layer described above (Fig. 11). Some appressorium cytoplasmic organelles migrated through the penetration peg (Fig. 11). The peg was about $400 \mathrm{~nm}$ wide where it passed through the cuticle. When it reached the upper epidermal wall a small infection vesicle was formed (Fig. 12). This infection vesicle, which developed intramurally, had an electron-dense content and an electron-transparent wall similar to the penetration peg (Fig. 13). Surrounding the infection vesicle, electron-dense deposits in the host wall were observed (Figs. 12, 13).

During the penetration phase, no morphological signs of the degradation of cuticular components were observed, but cuticle structure remained intact in those regions close to the infection pore (Figs. 12, 13).

Later on during the penetration phase, the cuticle located between well-developed infection vesicles and collapsed appressoria showed darks bands corresponding to folds and disruptions (Fig. 14).

The pathogen developed abundant hyphae from the infection vesicle in the subcuticular and intramural spaces. Host cell walls were highly degraded in the infected regions and this degradation could be occasionally seen around the invasion hyphae (Fig. 15). The highly degraded host wall showed an aspect of dilatation and it could have caused the folding and the distortion of the cuticle (Fig. 16). In fact, where the epidermal wall and the cuticle were separated the cuticle was often disrupted. In those regions of host tissue where the cuticle had large disruptions secondary infections by hyphae were facilitated (Fig. 17). Direct penetration from germinated conidia through small disruptions was also observed (Fig. 18).

At $24 \mathrm{~h}$ after inoculation, inter- and intra-cellular hyphae were detected in petioles using light microscopy and TEM. These hyphae were located in the second and third layer of the cortex, causing a high degree of disorganization in host cells and destroying over 10-20 host cells in this region (Figs. 19, 20). Concurrently, macroscopic symptoms appeared on the petiole-inoculated region as brownish spots of up to $1 \mathrm{~mm}$ in size. Forty-eight hours after inoculation, interand intra-cellular hyphae extended throughout the cortex, increasing the necrosis of the petiole tissue. At the macroscopic level, lesions that were lineal-shaped, 2-8 $\mathrm{mm}$ long, not sunken, brown and greenish-brown or orange-brown were observed.

The penetration process of $C$. acutatum in leaf tissues was similar to that in petioles; however, the pathogen was restricted to the subcuticular layer and did not progress into the leaf mesophyll spaces. Forty-eight hours after inoculation, in inoculated leaf tissues, intra- and inter-cellular hyphae were detected in the abaxial epidermis, but only intramural subcuticular hyphae were observed on the adaxial leaf side. Macroscopic symptoms, such as brownish spots (1 $\mathrm{mm}$ in diameter), were only observed on the abaxial leaf surface.

\section{Discussion}

This is the first report, at the ultrastructural level, of the earliest stages of penetration of $C$. acutatum in strawberry tissues by the formation of a penetration peg via an appres- 


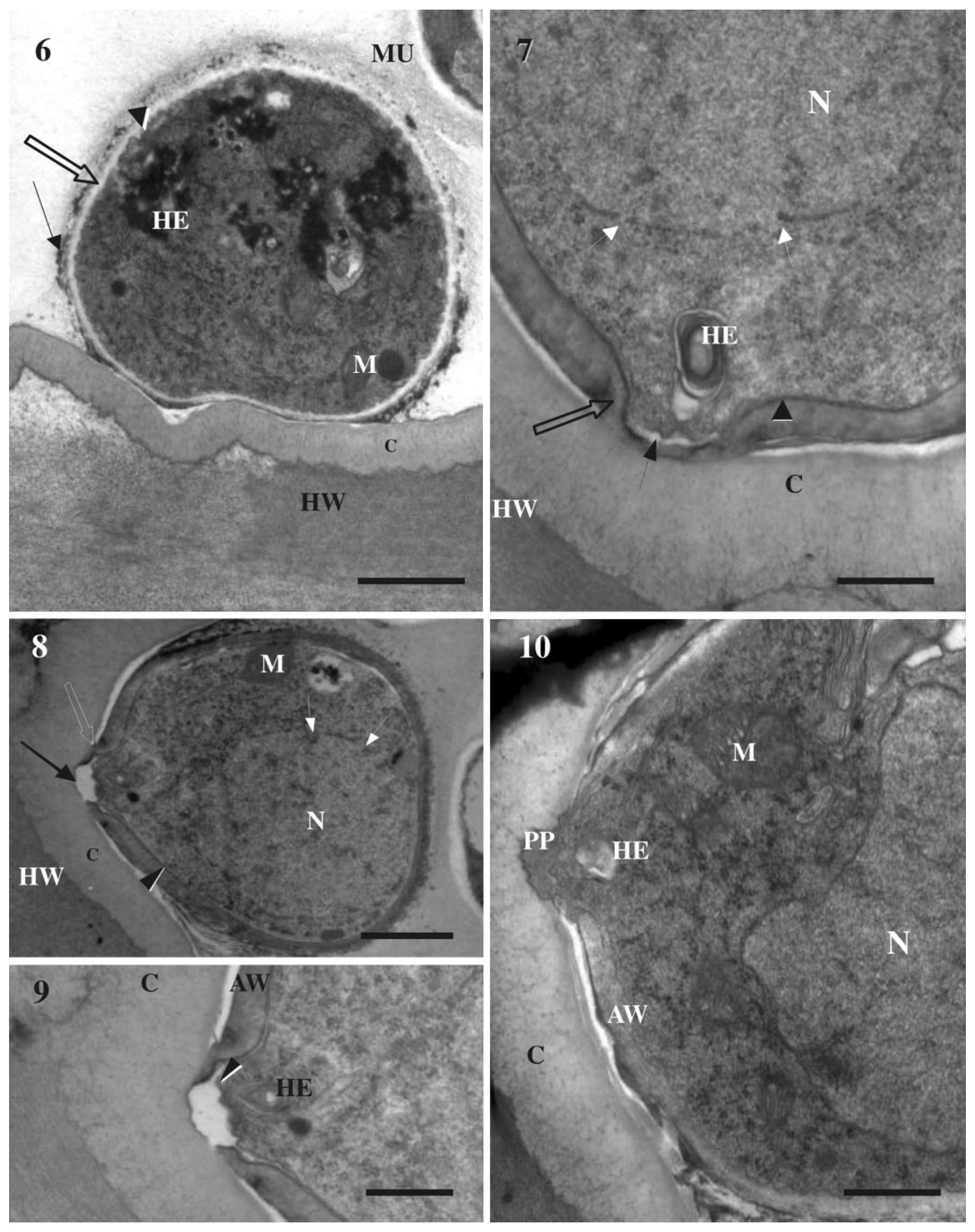


Figs. 11-13. Formation and development of penetration peg by Colletotrichum acutatum in strawberry petioles at 24 hpi (TEM). Fig. 11. Appressorium organelles (arrowhead) in penetration peg (PP) and peg wall (arrow). Scale bar $=0.5 \mu \mathrm{m}$. Fig. 12 . Penetration peg (PP), small intramural infection vesicle (IV), and electron-dense deposits (open arrows) in host cell wall (HW) surrounding infection vesicle (IV). Scale bar $=0.5 \mu \mathrm{m}$. Fig. 13. Intramural development of infection vesicle (IV), peg wall (solid arrows), electron-dense deposits in host cell wall (open arrow), mitochondria $(\mathrm{M})$ near pore, and wavy plasma membrane (arrowhead). Scale bar $=0.5 \mu \mathrm{m}$. AW, appressorial wall; C, cuticle; HE, heterophagosome; HW, host wall.
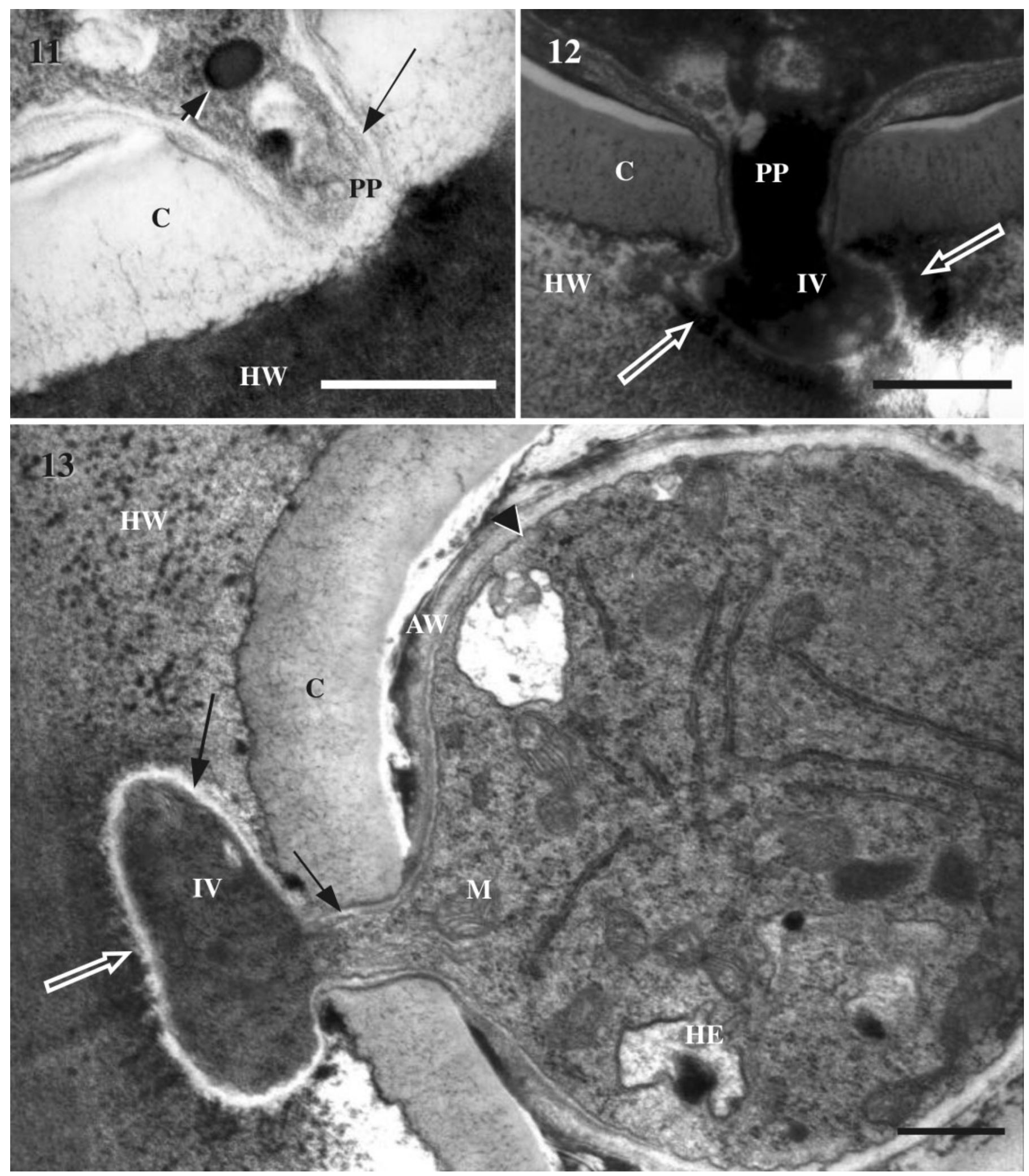
Figs. 14-17. Advanced stages of infection in petioles by Colletotrichum acutatum at 24 hpi. Fig. 14. Cuticle (C) between collapsed appressorium (A) and intramural infection vesicle (IV) showing dark bands that correspond to folds (arrowhead) and disruption (arrow). Degradation of the host cell wall $(\mathrm{HW})$ is visible $(*)$. Scale bar $=0.5 \mu \mathrm{m}$. Fig. 15. Degradation $(*)$ of host cell wall $(\mathrm{HW})$ in region close to invasion hypha $(\mathrm{H})$. Scale bar $=0.5 \mu \mathrm{m}$. Fig. 16. Cuticle $(\mathrm{C})$ is folded and distorted in the presence of a subcuticular hypha $(\mathrm{H})$. Subjacent epidermal cell $(\mathrm{EC})$ with no visible signs of alteration is also shown. Scale bar $=1 \mu \mathrm{m}$. Fig. 17 . Secondary infections owing to massive invasion of hyphae $(\mathrm{H})$ in a region where cuticle $(\mathrm{C})$ is distorted and broken (arrows). High degrees of degradation of the host cell wall $(*)$ are also shown. Scale bar $=1 \mu \mathrm{m}$. Fig. 18. Direct penetration from a germinated conidium (CO) of Colletotrichum acutatum in strawberry tissues at 24 hpi (TEM). Penetration is through a small cuticle (C) disruption (arrow) that produces an invasion hypha $(\mathrm{H})$ into host cell wall $(\mathrm{HW})$. Scale bar $=1 \mu \mathrm{m}$.
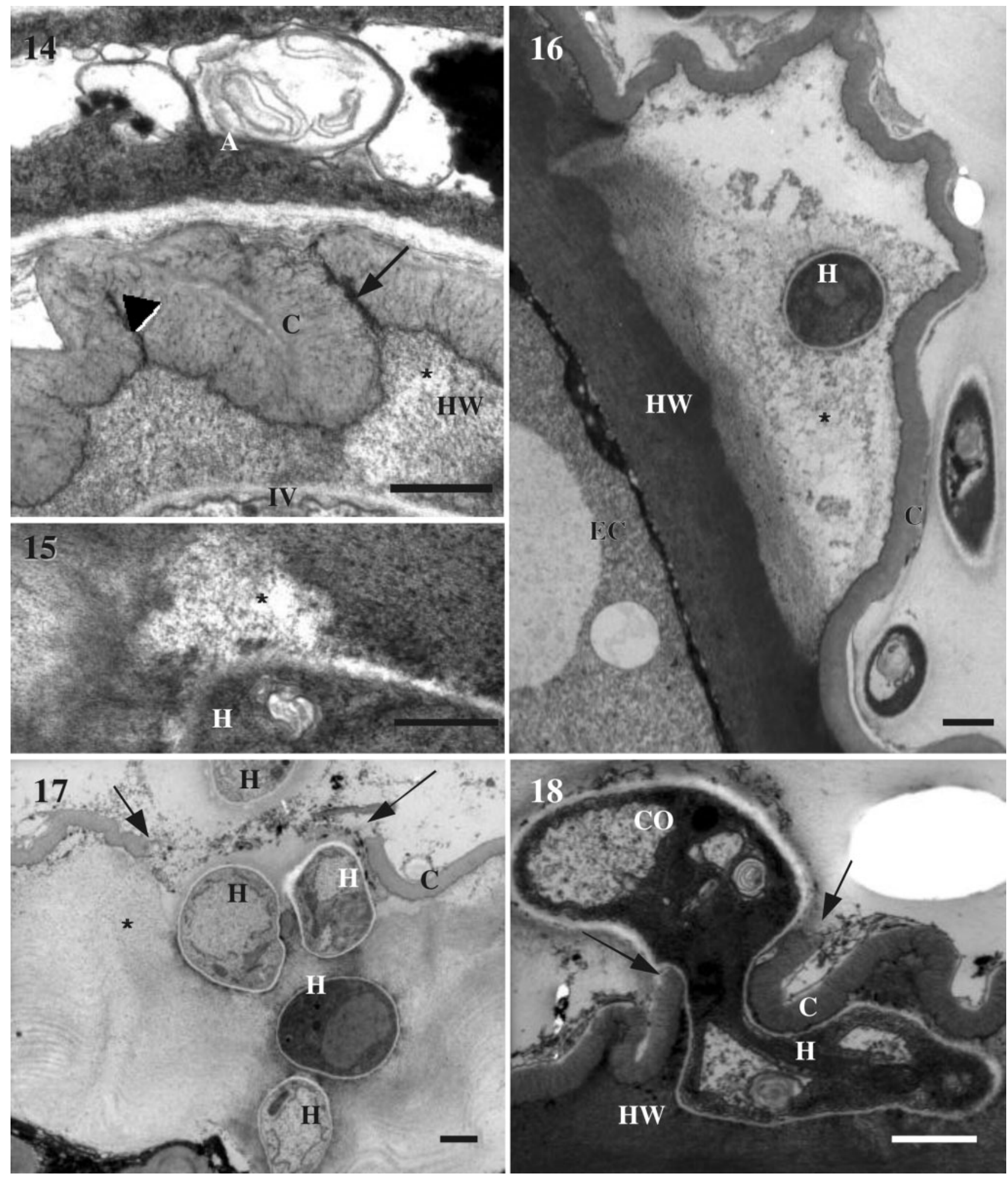
Figs. 19-20. Colonization of strawberry petioles tissues by Colletotrichum acutatum. Fig. 19. Light micrograph of the invasion of C. acutatum in petioles tissues at $24 \mathrm{hpi}$. Secondary infections through disrupted cuticle regions (open arrow) and discoloration of the host cell wall are visible in degradated regions (*). Subcuticular, intramural, intercellular, and intracellular hyphae (solid arrows) in the second and third layer of cortex are shown. Scale bar $=20 \mu \mathrm{m}$. Fig. 20. TEM micrograph of C. acutatum in petiole cortex cells at 24 hpi. Intramural and intracellular hyphae $(\mathrm{H})$ with degraded host cell wall $(*)$ and hyphae in the host cell (arrow) are shown. Scale bar $=2 \mu \mathrm{m}$.

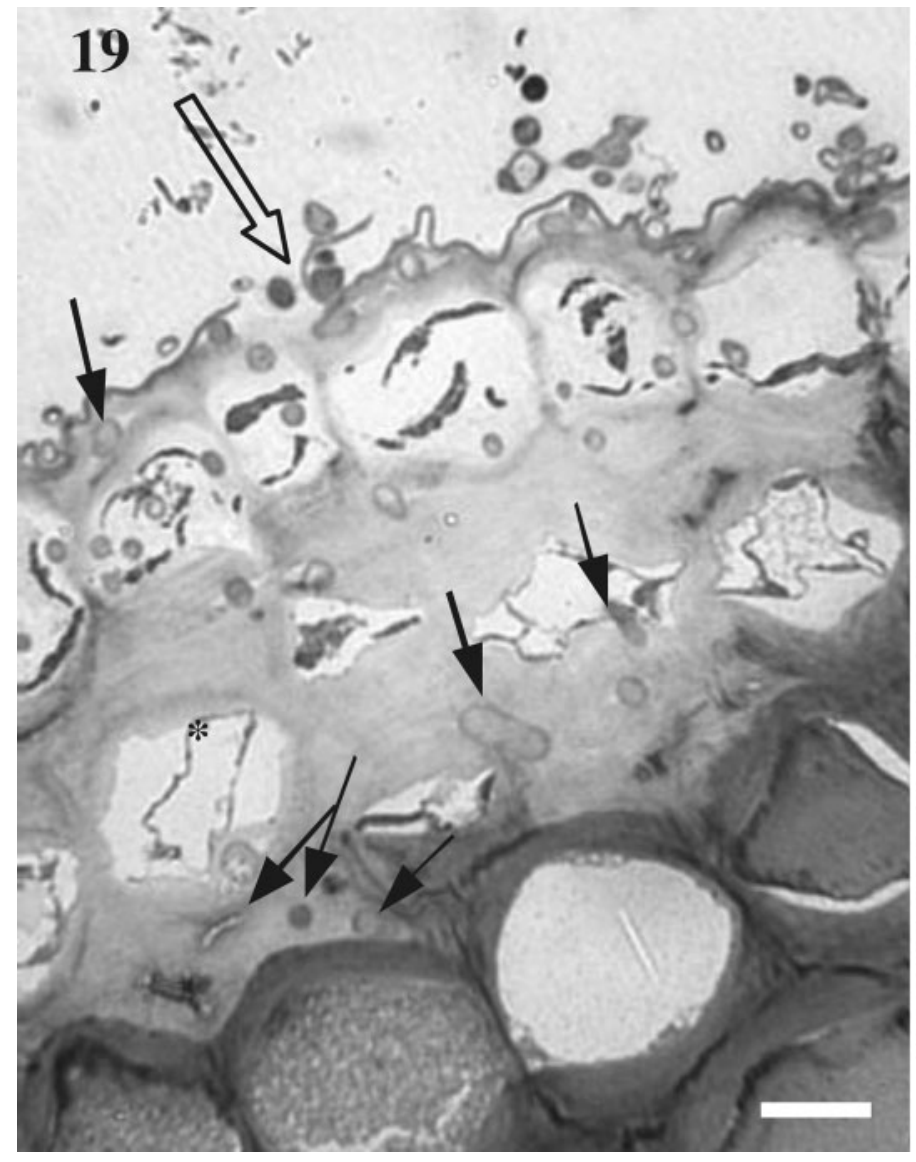

sorium and a subcuticular and intramural infection vesicle. The penetration peg has been observed and described at the ultrastructural level in other Colletotrichum spp. that infect other hosts (Coates et al. 1993; Latunde-Dada et al. 1996; Mercer et al. 1975; Mould et al. 1991b; O'Connell et al. 1985; Politis and Wheeler 1973; Wharton et al. 2001; Xuei et al. 1988). Curry et al. (2002) mentioned, but did not describe, the formation of the penetration peg from appressoria of $C$. fragariae infecting strawberry tissues, at the light microscope level but not the ultrastructural level. This is also the first report showing the subcuticular and intramural infection vesicle from $C$. acutatum during the early infection process of strawberry tissues and demonstrates that it behaves as a subcuticular and intramural pathogen according to infection strategies previously described by Bailey et al. (1992).

Pre-penetration events from germination to appressorium formation were similar to those described for other species of Colletotrichum (Dickman 2000). Microcyclic conidiation or conidiogenesis was observed on both adaxial and abaxial surfaces of attached strawberry leaves. This process has already been described in $C$. capsici on cowpea leaves (Latunde-Dada et al. 1999) and in C. acutatum on detached

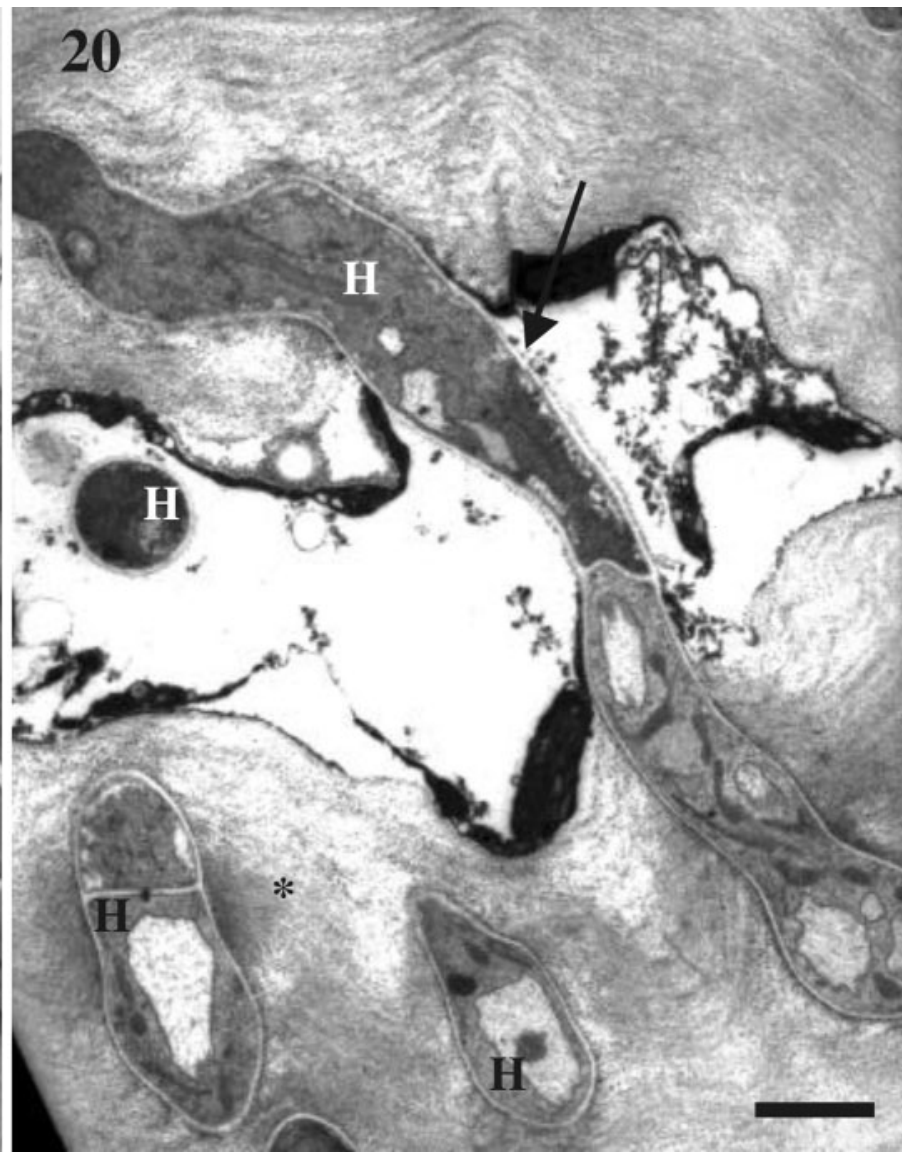

(Leandro et al. 2001) and attached (Horowitz et al. (2002) strawberry leaves, which may have implications on disease epidemics. However, on strawberry petioles, conidiogenic structures were not found. In previous work, strawberry leaves were less susceptible to $C$. acutatum infection than petioles (Arroyo et al. 2001; De los Santos 1998). Leandro et al. (2001) suggested that the production of secondary conidia may increase inoculum when susceptible tissue is not available. This is correlated with the observation of more severe macroscopic symptoms on petioles than on foliar tissues, that may be explained by the limited penetration observed on leaves.

The penetration phase of $C$. acutatum on strawberry tissues was not a synchronous process, as previously described for other Colletotrichum spp. on other hosts (O'Connell et al. 1985; Makowski and Mortensen 1998). Our work shows a detailed description, at the ultrastructural level, of different appressoria maturation stages of C. acutatum, before, during, and after their differentiation or melanization, which occurs at approximately the same time that appressorial pore formation begins (Leandro et al. 2001). During the penetration phase, the observation of a clean disruption of the cuticle, which does not display signs of degradation, supports 
the hypothesis that penetration could be based on mechanical forces (Mercer et al. 1975; O'Connell et al. 1985). Nevertheless, other factors such as the action of extracellular enzymes during the penetration process can not be excluded (Manandhar et al. 1985; O'Connell et al. 1985). The existence of appressoria whose plasma membranes show a smooth appearance at the penetration time, which could be related to an increased turgor pressure, also supports this hypothesis. Howard et al. (1991) reported that high turgor pressure in the appressorium is essential for mechanical penetration. Horowitz et al. (2002) observed collapsed appressoria after penetration, which they related to losses of turgor pressure in these structures.

Whereas other species of Colletotrichum produce a penetration peg and develop an intracellular infection vesicle (Bailey et al. 1990; Latunde-Dada et al. 1996; O'Connell et al. 1985; Wharton et al. 2001), C. acutatum produces a penetration peg that develops a subcuticular and intramural infection vesicle. These results demonstrate that this pathogen uses a subcuticular intramural invasion strategy, which is related to species with a wide host range that are considered generalist invaders (Bailey et al. 1992). However, Curry et al. (2002) left some uncertainly about calling this fungus hemibiotrophs because of the brevity of the biotrophic phase in $C$. acutatum. In our observations, the biotrophic phase on petioles was very brief, occurring during the period between 12 and $24 \mathrm{~h}$ after inoculation, similar to that described by Curry et al. (2002).

At $24 \mathrm{~h}$ after inoculation, host cell necrosis is less severe in foliar tisues than in petioles, so the biotrophic phase may be prolonged in the foliar tissue and the pathogen may remain within the plant cell wall longer without causing macroscopically visible lesions. Therefore, this symptomless stage in the leaf tissues would facilitate the survival of C. acutatum and represent a source of inoculum for further infections. The presence of subcuticular, intramural, and intra- or inter-cellular hyphae in leaf tissues disagrees with results of Leandro et al. (2001), who did not detect host penetration of strawberry leaves by $C$. acutatum. However, our observations agree with those of Horowitz et al. (2002), who detected the fungus inside strawberry leaves.

The observation of electron-dense deposits of unknown nature around the infection vesicle suggests a defence reaction of the plant to the presence of C. acutatum. In other host-pathogen interactions involving Colletotrichum spp., an electron-dense material called papilla has been found in the plant cell wall. This is a nonspecific response of the host in reaction to the presence of the pathogen (Bailey et al. 1990; Mercer et al. 1975; Mould et al. 1991b; O'Connell et al. 1985). In most instances, these electron-dense deposits are not capable of stopping the invasion of the pathogen (Mould et al. 1991b).

During the host tissue invasion process the host walls appeared highly degraded, presumably because of pathogen enzymes (Fernando et al. 2001). This degradation and disorganisation of the host walls caused dilatation and occasionally the disruption of the cuticle. This phenomenon has already been observed in alfalfa infected by $C$. trifolii (Porto et al. 1988).

This ultrastructural study of the infection process in petioles and leaves of strawberry by $C$. acutatum supports a dif- ferent response of both tissues to this pathogen, which had already been observed at the macroscopic level. It is unknown which mechanisms could be used by the foliar tissue to limit the invasion of $C$. acutatum and keep it in a symptomless stage.

\section{Acknowledgments}

We gratefully acknowledge the collaboration of Asunción Sánchez Contreras (CIFA Las Torres-Tomejil), Remedios García Navarro (Departamento Biología Celular de la Universidad de Sevilla), and José María Sanabria (Servicio de Microscopía Electrónica de la Universidad de Sevilla) for their invaluable technical support.

\section{References}

Arroyo, F.T., Moreno, F.J., García-Herdugo, G., and Romero, F. 2001. Respuesta diferencial de Colletotrichum acutatum y del tejido foliar en plantas de fresa. [Differential response of Colletotrichum acutatum and the foliar tissue in strawberry plants.] In IV Seminario Científico Internacional de Protección de Plantas, $41^{\text {a }}$ Reunión Anual de la Sociedad de Fitopatología de América-División Caribe (APS-CD), Varadero, Cuba, 14 July 2001. Impresos Plaza América, Varadera, Cuba. p. 117.

Bailey, J.A., Nash, C., and O'Connell, R.J. 1990. Infection process and host specificity of a Colletotrichum species causing anthracnose disease of cowpea, Vigna unguiculata. Mycol. Res. 94: 810-814.

Bailey, J.A., O'Connell, R.J., Pring, R.J., and Nash, C. 1992. Infection strategies of Colletotrichum species. In Colletotrichum: Biology, pathology and control. Edited by J.A. Bailey and M.J. Jeger. CAB International, Wallingford, UK. pp. 88-120.

Coates, L.M., Muirhead, I.F., Irwin, J.A.G., and Gowanlock, D. 1993. Initial infection processes by Colletotrichum gloeosporioides on avocado fruit. Mycol. Res. 97: 1363-1370.

Curry, K.J., Abril, M., Avant, J.B., and Smith, B.J. 2002. Strawberry anthracnose: Histopathology of Colletotrichum acutatum and C. fragariae. Phytopathology, 92: 1055-1063.

Dashek, W.V., and Mayfield, J.E. 2000. Methods for the ultrastructural analysis of plant cells and tissues. In Methods in plant electron microscopy and cytochemistry. Edited by W.V. Dashek. Humana Press. Totowa, N.J. pp. 195-214.

De los Santos, B. 1998. Estudio epifitótico, posibilidades de control de la antracnosis de fresa en el S.O. de Andalucía. Criterios morfológicos, culturales, bioquímicos y patogénicos en la caracterización del agente causal. Ph.D. thesis, Biología Vegetal y Ecología, University of Sevilla, Sevilla, Spain.

De los Santos, B., and Romero, F. 1999. Occurrence of Colletotrichum acutatum, causal organism of strawberry anthracnose in South-western Spain. Plant Dis. 83: 301.

Denoyes, B., and Baudry, A. 1995. Species identification and pathogenicity study of French Colletotrichum strains isolated from strawberry using morphological and cultural characteristics. Phytopathology, 85: 53-57.

Dickman, M.B. 2000. Colletotrichum. In Fungal pathology Edited by J.W. Kronstad. Kluwer Academic Publishers, Dordrecht, The Netherlands. pp. 127-147.

Fernando, T.H.P.S., Jayasinghe, C.K., and Wijesundera, R.L.C. 2001. Cell wall degrading enzyme secretion by Colletotrichum acutatum, the causative fungus of secondary leaf fall of Hevea brasiliensis. Mycol. Res. 105: 195-201.

Hancock, J.F. 1999. Strawberries. CABI Publishing, New York. 
Horowitz, S., Freeman, S., and Sharon, A. 2002. Use of green fluorescent protein-transgenic strains to study pathogenic and nonpathogenic lifestyles in Colletotrichum acutatum. Phytopathology, 92: 743-749.

Howard, C.M., Maas, J.L., Chandler, C.K., and Albregts, E.E. 1992. Anthracnose of strawberry caused by the Colletotrichum complex in Florida. Plant Dis. 76: 976-981.

Howard, R.J., Ferrari, M.A., Roach, D.H., and Money, N.P. 1991. Penetration of hard substrates by a fungus employing enormous turgor pressures. Proc. Natl. Acad. Sci. U.S.A. 88: 1128111284.

Latunde-Dada, A.O., O’Connell, R.J., Nash, C., Pring, R.J., Lucas, J.A., and Bailey, J.A. 1996. Infection process and identity of the hemibiotrophic anthracnose fungus (Colletotrichum destructivum) from cowpea (Vigna unguiculata). Mycol. Res. 100: 1133-1141.

Latunde-Dada, A.O., O'Connell, R.J., Nash, C., and Lucas, J.A. 1999. Stomatal penetration of cowpea (Vigna unguiculata) leaves by a Colletotrichum species causing latent anthracnose. Plant Pathol. 48: 777-784.

Leandro, L.F.S., Gleason, M.L., Nutter, F.W., Wegulo, S.N., and Dixon, P.M. 2001. Germination and sporulation of Colletotrichum acutatum on symptomless strawberry leaves. Phytopathology, 91: 659-664.

Makowski, R.M.D., and Mortensen, K. 1998. Latent infections and penetration of the bioherbicide agent Colletotrichum gloeosporioides f. sp. malvae in non-target field crops under controlled environmental conditions. Mycol. Res. 102: 15451552.

Manandhar, J.B., Kunwar, I.K., Singh, T., Hartman, G.L., and Sinclair, J.B. 1985. Penetration and infection of soybean leaf tissues by Colletotrichum truncatum and Glomerella glycines. Phytopathology, 75: 704-708.

Mercer, P.C., Wood, R.K.S., and Gerenwood, A.D. 1975. Ultrastructure of the parasitism of Phaseolus vulgaris by Colletotrichum lindemuthianum. Physiol. Plant Pathol. 5: 203214.
Morin, L., Derby, J.L., and Kokko, E.G. 1996. Infection process of Colletotrichum gloeosporioides f. sp. malvae on Malvaceae weeds. Mycol. Res. 100: 165-172.

Mould, M.J.R., Boland, G.J., and Robb, J. 1991a. Ultrastructure of the Colletotrichum trifolii - Medicago sativa pathosystem. I. Pre-penetration events. Physiol. Mol. Plant Pathol. 38: 179-194.

Mould, M.J.R., Boland, G.J., and Robb, J. 1991b. Ultrastructure of the Colletotrichum trifolii - Medicago sativa pathosystem. II. Post-penetration events. Physiol. Mol. Plant Pathol. 38: 195210.

O'Connell, R.J., Bailey, J.A., and Richmond, D.V. 1985. Cytology and physiology of infection of Phaseolus vulgaris by Colletotrichum lindemuthianum. Physiol. Plant Pathol. 27: 7598.

Politis, D.J., and Wheeler, H. 1973. Ultrastructural study of penetration of maize leaves by Colletotrichum graminicola. Physiol. Plant Pathol. 3: 465-471.

Porto, M.D.M., Grau, C.R., de Zoeten, G.A., and Gaard, G. 1988. Histopathology of Colletotrichum trifolii on alfalfa. Phytopathology, 78: 345-349.

Pring, J.R., Nash, C., Zakaria, M., and Bailey, J.A. 1995. Infection process and host range of Colletotrichum capsici. Physiol. Mol. Plant Pathol. 46: 137-152.

Skipp, R.A., and Deverall, B.J. 1972. Relationship between fungal growth and host changes visible by light microscopy during infection of bean hypocotyls (Phaseolus vulgaris) susceptible and resistant to physiological races of Colletotrichum lindemuthianum. Physiol. Plant Pathol. 2: 357-374.

Wharton, P.S., Julian, A.M., and O'Connell, R.J. 2001. Ultrastructure of the infection of Sorghum bicolor by Colletotrichum sublineolum. Phytopathology, 91: 149-158.

Xuei, X.L., Järlfors, U., and Kuc', J. 1988. Ultrastructural changes associated with induced systemic resistance of cucumber to disease: host response and development of Colletotrichum lagenarium in systemically protected leaves. Can. J. Bot. 66: 1028-1038. 